\title{
INVESTIGATING CULTURAL CONTENTS OF READING PASSAGES IN THE TESTS DEVELOPED BY ENGLISH TEACHERS IN A SENIOR HIGH SCHOOL
}

\author{
Ihsan Nur Iman Faris \\ Faculty of Postgraduates Studies, Indonesia University of Education \\ Address: Jl. Dr. Setiabudhi 229 Bandung 40154 Bandung, West Java, Indonesia \\ E-mail: ihsannif@gmail.com
}

\begin{abstract}
Cultural contents contained in reading passages need to be treated carefully due to their influence to shapethe readers' points of view. Since a test can include reading passages, careful selection of reading passages should also be conducted in a test development. This research is aimed at investigating what cultures are contained in the reading passages of the tests developed by the English teachers in a senior high school and the reasons why the reading passages were included. The methods employed in this research were textual analysis and case study. The data for textual analysis were collected from 24 reading passages from the tests developed by the English teachers of a senior high school in Cianjur, West Java, Indonesia. The information related to the problems of inclusion of cultural contents in the tests was collected from an interview. Among 24 reading passages in the tests, 10 reading passages were culture-neutral, while 14 reading passages contained cultural items. The findings show that in 14 reading passages, the culture contained are the target culture (40\%) in the forms of naming, place, and season, the international culture (40\%) in the forms of naming, place, and season, and the source culture (20\%) in the forms of naming and place. Theunbalance proportion of the source culture can influence the readers' mindset and the result of the test due to familiarity issue of the materials. Regarding why this proportion is found in the tests, the teachers were not aware of the cultural content issue. Therefore, the proportion was not intentionally made. The unawareness of teacher can lead to the inclusion of inappropriate cultural contents in the tests. Hence, based on the findings, it is recommended that teachers be more aware of cultural contents in reading passages and develop a test with a more balance proportion of cultural contents in reading passages.
\end{abstract}

Keywords: Cultural contents, the source culture, the target culture, the international culture, reading passages.

\begin{abstract}
Abstrak
Isi budaya yang terkandung dalam wacana harus diperlakukan dengan hati-hati karena bisa mempengaruhi sudut pandang pembaca. Dikarenakan tes mencakup wacana, pemilihan wacana secara hati-hati juga harus dilakukan dalam pengembangan tes. Penelitian ini bertujuan untuk menyelidiki budaya apa yang
\end{abstract}


terkandung dalam wacana-wacana di dalam tes yang dikembangkan oleh guru bahasa Inggris di SMA dan alasan mengapa wacana tersebut dimasukkan. Metode yang digunakan dalam penelitian ini adalah analisis tekstual dan studi kasus. Data untuk analisis tekstual dikumpulkan dari 24 wacana dari tes yang dikembangkan oleh guru bahasa Inggris dari SMA di Cianjur, Jawa Barat, Indonesia. Informasi yang berhubungan dengan masalah masuknya isi budaya dalam tes dikumpulkan dari wawancara. Di antara 24 wacana tes, 10 wacana netral dari budaya, sementara 14 mengandung temuan budaya. Hasil menunjukkan bahwa dari 14 wacana, budaya yang terkandung adalah budaya target (40\%) dalam bentuk penamaan, tempat, dan musim, budaya internasional (40\%) dalam bentuk penamaan, tempat, dan musim, dan budaya sumber (20\%) dalam bentuk penamaan dan tempat. Proporsi budaya yang tidak imbang dapat mempengaruhi pola pikir pembaca dan hasil tes karena berkaitan dengan tingkat pengetahuan terhadap materi. Mengenai mengapa proporsi ini ditemukan dalam tes, guru tidak menyadari masalah konten budaya. Oleh karena itu, proporsi tidak sengaja dibuat. Ketidaksadaran guru dapat menyebabkan masuknya isi budaya yang tidak pantas ke dalam tes. Oleh karena itu, berdasarkan temuan, disarankan bahwa guru menjadi lebih sadar akan isi budaya dalam wacana dan mengembangkan tes dengan menjaga keseimbangan proporsi isi budaya dalam wacana.

Kata kunci: Isi budaya, budaya sumber, budaya target, budaya internasional, wacana.

\section{INTRODUCTION}

Culture has become one of the concerned issues in the field of language testing and evaluation. The background and cultural knowledge of test takers need to be considered in the development of a test since it will affect the way a test is dealt with (Weir, 2005). If cultural issues in a test are not treated carefully, the tendency of bias found can be high (Vijver \& Tanzer, 2004). To solve the problems of cultural bias, the methods such as Item Response Theory (IRT) and Confirmatory Factor Analysis (CFA) which generally employ statistical approaches to detect biased items in a test can be utilized (Djiwandono, 2006; Meade \& Fetzer, 2009). After biased items are detected, the items are revised or removed from a test.If cultural bias in a test has been taken care, the aim of a test at measuring the proficiency of test takers regardless their cultural background (Djiwandono, 2006) can be achieved. However, albeit a plethora of efforts dealing with cultural bias in a test has been conducted, the research concerning how culture is portrayed in reading passages of a test is still limited. The consideration of cultural issue in reading passages of a test is crucial since unbalance proportion of cultural contents can make test takers do not understand the reading passages optimally due to unfamiliarity to the materials included (Gass \& Selinker, 2008). Hence, unbalance proportion of 
cultural contents in the reading passages to some extent can also lead to cultural bias in a test.

As English has been considered an international language spoken by many non-native speakers around the world (see for example Jenkins, 2009; Crystal, 2003; McKay, 2003), how English treated in the education field has changed in some parts of the world. The teaching of English emphasizing the achievement of intelligibility has been encouraged (Canagarajah, 2007) and textbooks used as the guidance in teaching-learning activities are suggested to include more non-native speaker characters and source culture issues in the reading passages (Matsuda, 2003; Xiao, 2010). The efforts are aimed at realizing teachers and students of their ownership ofEnglish, therefore, they can internalize the language to tell about their own culture and condition (Sherman, 2010; McKay, 2003). Hence, as assessment is considered one of the influential factors directing the teaching of English in a classroom (Brown, 2000), the integration of other cultures aside from the target cultures should be conducted.

In Indonesia the teaching of Englishis geared toward encouraging students to be civilized citizens possessing appropriate behaviors. As the notions of appropriateness differ from one country to another (Piller, 2001), the behaviors which are embedded in the teaching of English should be based on Indonesian cultures and ideologies. Hence, in order to make English as the tool for shaping students' behavior based on standard of appropriateness applied in Indonesia, the culture of Indonesia should be integrated into teaching materials. The integration of other culture in English text is possible since one of the criteria indicating English as an international language is that it enables other culture to be conveyed in this language (McKay, 2003). The integration of other cultures into English can be found for instance in reading passages contained in textbooks (McGrath, 2002). The selection of reading passages should be treated carefully since according to Sherman (2010), texts in stextbooks can determines what knowledge students should be exposed to and encourage students to support certain believes contained in texts.

Hermawan and Noerkhasanah (2012) found that source culture contents are prominent in the reading passages of the primary English textbooks in Indonesia. The findings that source culture contents are prominent in the reading passages of the textbooks are also found by Elgar (2012) investigating the English textbooks in Brunei Darussalam. In contrast, different findings were reported by Matsuda (2003) finding the target culture contents are predominant in the English textbook for Japanese context, and Xiao (2010) who found that the target cultures are represented more in the English textbooks in China. Moreover, Sherman (2010) found that in some TESOL textbooks, non-native speakers are portrayed in biased ways where their communicative prominence, participant roles, and power are implied inferior compared to native speakers. As reading passages can also be found in a test, especially in a reading comprehension test, there is also a tendency that particular cultural values are contained in reading passages of a test. Although some notable research 
have been conducted to investigate cultural contents in reading passages of textbooks, the investigation of cultural contents in reading passages of tests are still limited.

This research is aimed at investigating the cultural contents contained in the reading passages of the tests designed by the teachers of a senior high school in Cianjur. The notion of English as an international language is employed as the approach. This research is descriptive qualitative in nature. The culture in this research is categorized into the source culture, the target culture, and the international culture (Cortazzi \& Jinn, 1999). Mainly this research is geared toward answering the following research questions (1) what cultures are contained in the reading passages of the tests designed by the English teachers of the senior high school in Cianjur? (2) why did the English teachers of the senior high school in Cianjur include the reading passages to the tests?

The results of this study are expected to enrich the theories of English language assessment and English as an international language. The results of this study are also expected to help teachers to develop language testing in line with the notions of English as an international language and the objective of national education. By reflecting from this research, it is expected that teachers can analyze the strengths and weaknesses of the tests designed by the teachers involved in this study, then apply the strengths and refine the weaknesses.

\section{Culture in Language Testing}

Thwaites, Davis, and Mules (1994, p.1) defined culture as "the ensemble of social processes by which meanings are produced, circulated, and exchanged". All aspects in society such as economy, politics, family life and education basically are concerned with culture. Thus, the term culture may refer to various aspects of life. In its relation to language, culture and language are two inseparable things (Brown, 2000; Kramsch, 1991). Holmes (2001) states that people's perception and behavior are strongly influenced by the language used. Thus, since language and culture are inseparable, and culture permeates the system of education, language testing and evaluation which are the part of education are also inseparable with the culture learning process.

The issue of culture has become one of the concerns in the field of language testing. How test items are correlated with cultural backgrounds of the test takers is one of the issues analyzed. It is said that the difference of test scores obtained among people from various cultural backgrounds may be caused by cultural bias (Vijver \& Tanzer, 2004). The relevancy can be found from Weir (2005) stating that cultural knowledge of test takers can affect how a test is dealt with. A test is considered culture-bias free if test takers with the same ability on the construct being measured obtain the same scores regardless their cultural background (Djiwandono, 2006).When the cultural background of test takers influences test results, then it can be caused by cultural bias which based on Vijver \& Tanzer (2005) is categorized into (1) construct bias (2) method bias and (3) item bias. To solve the problems of cultural bias, the methods such as Item Response Theory (IRT) and Confirmatory Factor 
Analysis (CFA) which generally employ statistical approaches to detect the biased items in the test can be utilized (Djiwandono, 2006; Meade \& Fetzer, 2009). The biased items detected are revised or removed from the texts after analysis has been conducted.

In the other words, culture in the language testing and evaluation generally is related to how a test is culturally accepted in terms of delivery and item creation. If a test item asking about particular culture is accompanied by the explanation in the text, then a test is not considered culture-biased since the answer related to culture is based on text comprehension. However, the consideration of cultural issue in reading passages of a test is crucial since unbalance proportion of cultural materials can make test takers do not understand optimally reading passagesin a test due to unfamiliarity to cultural contents included (Gass \& Selinker, 2008). Culture in reading passages of the test can also influence how test takers, in this case students, see particular culture (Sherman, 2010; Aliakbari, 2004).Hence, unbalance proportion of cultural contents in the reading passages to some extent can also lead to cultural bias in a test.

\section{English as an International Language}

English is now used in almost every country in the world. The number of people speaking English as their second or foreign language is even more than people speaking English as their first language (Brown, 2000; Jenkins, 2009). The model of the spread of English proposed by Kachru (1992 cited in Jenkins 2009) portrays the English world and the categorization of English speakers around the world. The detailed picture of the three-concentric circle model proposed by Kachru (1992 cited in Jenkins, 2009) is as follows:

\section{Kachru's three-circle model of World Englishes (taken from Jenkins, 2009, p.19)}

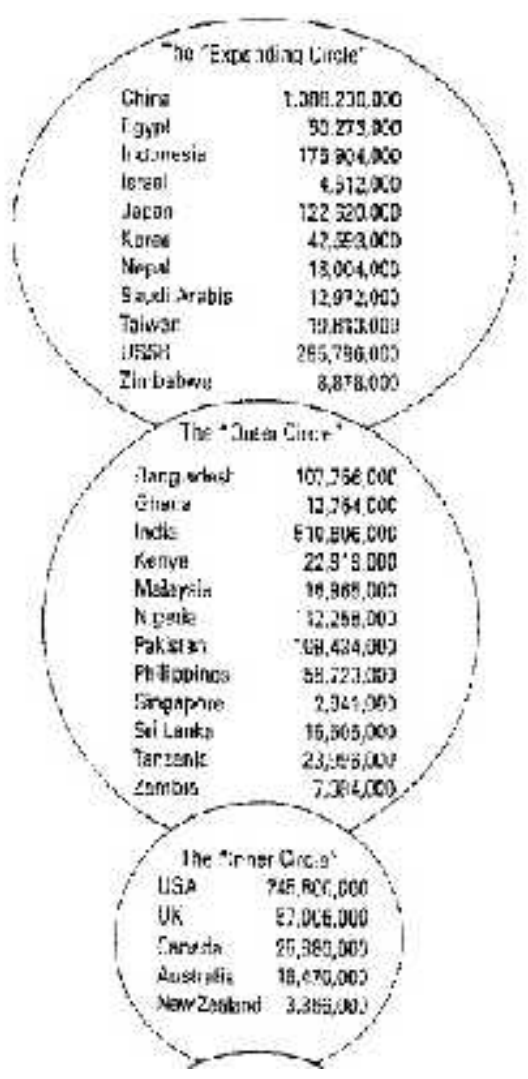


According to Jenkins (2009), unlike The Outer Circle Countries, The Expanding Circle Countries should follow the norm of The Inner Circle Countries in speaking English. This notion is argued by some scholars (Crystal, 2003; Matusda, 2003; McKay, 2003; Yano, 2001) believing that as English has become an international language spoken in the contexts of various speakers, norms and cultures of English should not only be related to native speakers. This argument has been permeated into English education. The teaching of English emphasizing the achievement of intelligibility has been encouraged (Canagarajah, 2007) and textbooks considered as one of crucial elements in English teaching (Hutchinson and Torres, 1994; McGrath, 2002; Dudley-Evans and John, 2009) have begun portraying Culture of The Outer Circle Countries and The Expanding Circles countries. It is beneficial for language teachinglearning since if cultural situations of the readers are portrayed in the reading passages they read; they can learn the language more effectively (Gass \& Selinker, 2008). Although the portrayals of Culture of The Outer Circle Countries and The Expanding Circle Countries are suggested, it does not mean that the target culture should not be portrayed in reading passages. The issue concerned here is in the balance portrayal of various cultures. As Kramsch (1991) suggest, learning other languages should promote intercultural understanding.

Some notable research investigating what cultures are portrayed in reading passages of textbooks has been conducted. Hermawan and Noerkhasanah (2012) found that the source culture contents are prominent in the reading passages of the primary English textbooks in Indonesia. Similar findings that source culture contents are prominent in the reading passages in the textbooks were also found by Elgar (2012) investigating the English textbooks in Brunei Darussalam. In contrast, different findings were reported by Matsuda (2003) finding the target cultures are predominant in the English textbook for Japanese context, and Xiao (2010) who also found that the target culture are represented more in the English textbooks in China. Moreover, Sherman (2010) found that in some TESOL textbooks, non-native speakers are portrayed in biased ways where their communicative prominence, participant roles, and power are implied inferior compared to native speakers. The findings are relevant to Kachru and Smith (2008) stating that American and British culture are the 'favorite' culture represented in textbooks. Cultural contents in reading passages should be treated carefully since it can influence how readers see particular culture (Sherman, 2010; Aliakbari, 2004). Hence, as reading passages can also be found in a test, the cultural contents included in a test should be considered carefully.

\section{The Categorization of Cultures}

Culture can be defined broadly and widely (Vivelo, 1997) in order to narrow down the investigation of culture in reading passages of the tests, culture in this research is categorized based on Cortazzi and Jin (1999) dividing culture into three categories. 
1. The source culture materials: referring to materials presenting language learners' own culture. The aims of the source culture materials are accommodating learners' need to talk about their culture with visitors and helping learners to be more aware of their own cultural identity.

2. The target culture materials: referring to materials presenting the culture of The Inner Circle countries which are The United States, The United Kingdom, Australia, Canada, and New Zealand. The aim of the target culture materials usually is exposing users to the cultural contexts of the target language.

3. The international culture materials: referring to materials presenting a wide variety of culture in The Outer Circle Countries and The Expanding Circles Countries or where English is not used as first or second language but as an international language such as in China and Brazil. The aims of the international culture materials are raising users' intercultural awareness and making users familiar with various sociocultural contexts.

The cultural contents of reading passages in the tests are categorized into the source culture, the target culture, and the international culture based on several sources such as "Culture and Customs of Indonesia" by Forshee (2006), "Culture and Customs of Australia" by Laurie Clancy (2004), "How Canadians Communicate: III" by Beaty, et al (2010), "New Zealand: Culture Shock - A Survival Guide to Customs and Etiquette" by Peter Oettli (2009), "British Culture: An Introduction" by David Christopher
(1999), "Culture and Customs of the United States" by Benjamin F. Shearer (2008) and "Beyond Language" by Adelman and Levine (1993). The international culture is identified based on the country mentioned in the reading passages and further research on various sources.

\section{Test Development}

In the process of a test development, the objective, reliability, and validity of a test usually are seen as the prominent aspects to be taken care. The indicators determining whether a test serves the objective, and is reliable and valid are explained systematically by some experts (see for example: Fulcher and Davidson, 2007, Weir, 2005; Brown, 2004). On the other hand, cultural bias and washback of a test development are relatively more difficult to identify since deeper analysis after the test is implemented needs to be conducted. Many variables and indicators need to be taken into consideration to determine whether a test is culturally biased or giving negative washback toward society.

In investigating cultural bias in a test, cultural background of test takers and whether the items can be answered because of their cultural background need to be investigated (Vijver and Tanzer, 2004). To know whether a test is valid in terms of construct, content, and appearance are not sufficient. On the other hand,in identifying the washback effect of a test, what should be analyzed are not only the test items and test developers.Teaching-learning process, teachers, students, and society involved in that test are variables that should also be analyzed in the investigation. A test inflicting negative 
washback to teaching learning process can be reliable and valid in terms of test development (Fulcher and Davidson, 2007). Hence, test developers may not be aware of what might happen due to the implementation of the test. The investigation of cultural contents of reading passages in a test seems to be treated in the similar way. A test containing reading passages containing inappropriate cultural values can be valid and measure language proficiency of test takers. The influence of values of reading passages may not influence the results of a test. Thus, there is a tendency that a test developer includes any reading passage to a test without deeper consideration.

\section{METHOD}

\section{Research Design}

This research generally is descriptive qualitative research attempting to "investigate quality of relationships, activities, situations, or materials" (Fraenkel, Wallen, \& Hyun, 2012, p.426). To answer the first research question, this research involved selecting text, determining the unit to be coded, developing content categories, and analyzing data. Thus, the method used is categorized into content analysis (Frey, et al, 1999). The data were categorized based on the types of culture in language materials by Cortazzi \& Jin (1999) to see what cultures are contained in the reading passages. To answer the second research question, semi-structured interview (Fraenkel, Wallen, \& Hyun, ibid) was employed to collect the data regarding the reasons why teachers include particular reading passages to the tests. The findings of this research then are analyzed and discussed qualitatively.

\section{Data Collection}

The data of this research were collected from 24 reading passages of the six tests and the interview with the English teachers of a senior high school in Cianjur developing the tests. The tests utilized as samples were: Ulangan Harian Bahasa Inggris Kelas XII 2014/2015 containing four reading passages, Ujian Tengah Semester Ganjil 2014/2015 Kelas X IPA \& IPS containing two reading passages, Ujian Tengah Semester Ganjil 2014/2015 Kelas XI Bahasa containing two reading passage, Ulangan Umum Semester Gasal 2014/2015 Kelas X IPA \& IPS, containing two reading passages, Ulangan Umum Semester Gasal 2014/2015 Kelas X Bahasa containing three reading passages, and Ulangan Umum Semester Gasal 2014/2015 Kelas XII Umum containing 11 reading passages. The reasons why the source was selected mainly were because of its practicability and usability. Practicability in this sense means that the source of the data was relatively easy to find. Usability refers to the usage of the tests especially in Cianjur, West Java.

The data of the research were in the form of reading passages. Reading passages were chosen since they have high possibility to contain cultural values (Adaskou, Britten \& Fahsi, 1990). The reading passages in the tests vary from narrative, descriptive, procedure, discussion, and explanation. The content of the reading passages then are categorized into the source culture, the target culture, the international culture, and culture-neutral contents. As elaborated previously, the 
source culture refers to the culture of teachers and learners, which in this research refers to Indonesian culture. The target culture refers to British, American, Canadian, Australian, and New Zealand cultures or the culture belong to The Inner Circle countries (Kachru, 1992 cited in Jenkins, 2009), and the international culture refers to cultures which do not belong to the source culture and the target culture. Culture neutral contents are contents in the textbook which do not refer to any culture such as a scientific explanation. Cultural items investigated in the reading passages are limited into art, literature, folklore, media, naming, place, customs, traditions, foods, and clothes.

The data were also collected from the interview with two teachers developing the tests. The teachers developing the tests were graduated from English education department of some universities and have learned about language testing and evaluation. The questions of the interview are related to how the teachers develop a test and why particular reading passages are included in the test. However, the questions could be modified based on the conditions and answers given by the participant. Thus, the interview was categorized as a semi-structured interview (Fraenkel, et al, 2012).

\section{Data Analysis}

Data analysis was divided into two main steps. First, in order to reveal what cultures are represented in the textbook, the contents in the reading passages were analyzed whether they are in the form of art, literature, folklore, media, naming, place, customs, traditions, foods, and clothes. Then, the cultural contents are categorized into the source culture, the target culture, the international culture, or culture-neutral (Cortazzi and Jin, 1999). The frequency of the data categorized was converted into percentages. The percentage was compared and analyzed to investigate what culture occurred most frequently in the tests. The findings then were discussed qualitatively. Moreover, in order to investigate why the teachers as the test developers include the reading passages in the text, the interview was conducted to collect the data. The data were analyzed based on elements of test development especially those related to cultural contents in language testing. The findings then are discussed qualitatively.

\section{RESULTS AND DISCUSSION What Cultures are Contained in Reading Passages of the Tests}

The data analysis conducted found that out of 24 reading passages, 14 reading passages $(58.33 \%)$ contain cultural values while 10 reading passages $(41.67 \%)$ are culture-neutral. The 10 reading passages containing no cultural values generally are scientific explanations about particular things. Those culture neutral reading passages do not include any character, place, custom, ideology, and term exclusively related to particular culture. In general, the cultures found in the reading passages are the source culture, the target culture, and the international culture. Those cultural contents were found from 14 reading passages with different proportion. The total number of cultural contents found in the tests is 20. One reading passages could contain more than one categories of culture. The 
proportion of cultural contents found in reading passages of the tests developed by English teachers in a senior high school in Cianjur, West Java is as follows:

\section{The proportion of cultural contents found in reading passages of the tests}

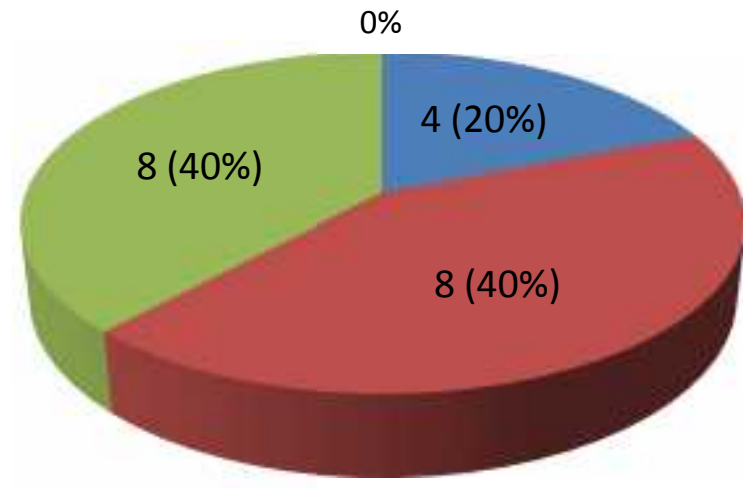

The source culture contents

The target culture contents

The international culture contents

From the chart above it can be seen that the target Culture contents and the international culture contents prominently share the same proportion, while The Source culture contents were found the least with only four items found or $20 \%$ of the total proportion. Hence, it can be concluded that the cultures contained in the reading passages of the tests are dominated by the target cultures and the international cultures.

The finding implies that the mindset of English as the language spoken by The Inner Circle Country people has begun to change. It can be seen how people from other culture have begun being portrayed in reading passages. Then, it corresponds to what Matsuda (2003) suggests regarding more inclusion of other characters beside native speakers in a reading passage. As contents of reading passages can influence points of view of readers (Sherman, 2010; Aliakbari, 2004), prominent portrayal of the international culture in reading passages of the tests can encourage teachers and students to think that English can accommodate communication not only with native speakers of English, but also with people around the world with various cultural background. This finding is not in line with Kachruand Smith (2008) stating that the target culture people, especially British and American, are usually favored in reading passages.

The target culture and the international culture were portrayed in quite similar ways. The name of characters and places mentioned are the 
main indicators that the reading passages contain the target culture and the international culture. Names introduced in the reading passages for instance are Sir Stamford Raffles, Peter Walker, Jason Brown, and Lucy Wang, while places mentioned for instances are Britain, Cambridge, Hongkong, and France. Folklore and seasons are also contributed to the number of the target culture and the international culture found in the reading passages. Folklore is found in the forms of Aesop Fable which is originated from Greece and the mention of Vampire which is originated from Romania, while seasons are categorized into the target culture and the international culture since winter and spring seasons cannot be found in the source culture yet can be found in other two categories of culture.The portrayal of the previously mentioned cultural contents can encourage intercultural understanding that Kramsch (1991) suggest to be the aim of including cultures into lessons. Moreover, intercultural understanding can be encouraged more effectively in the reading passage including more than once cultures, for instance in the one found in a test explaining Borobudur temple. In that reading passage, the source culture, the target culture, and the international culture comprised the whole explanation. Borobudur temple which is located in Indonesia is said to be found by Sir Stamford Raffles from England, and then was listed by UNESCO as one of World Heritage Sites. This kind of reading passage should be included more in a test.

On the other hand, the less portrayal of the source culture contents in the reading passages can make the tests be culturally biased since the test takers may find it difficult to understand the contents that they are not familiar with. Since according to Gass \& Selinker (2008), students learn language easier when they are familiar with the cultural context of the materials. Moreover, less portrayal of the source culture can trigger teachers and students to think that English is less practical to explain their own cultures. It is because familiar contexts of the readers are not accommodated by the language (Glass $\&$ Selinker, 2008) and the number of occurrences in reading passages signify that people from particular cultural background are inferior or superior toward other people (Sherman, 2010). If the portrayal of the source culture in the reading passages is less, the characteristics and behaviors which are expected to be built by learning English will not be attained. The proportion of the source culture values that students need to follow are less compared to the portrayal of other cultures. The more proportion of cultures which may not be in line with local values then can be more influential to build students mindset and characteristics. However, in terms of portrayal, the source culture is portrayed in non-judgmental way. The source culture contents are found in the form of naming and places. The names mentioned in reading passages for instance are Ratna Purbasari \& Kusworo, while the places mentioned for instance are Cianjur, Magelang, Borobudur, and Yogyakarta. Ratna Purbasari was portrayed as a transfer student whose hobbies were reading novels and watching movies and she wanted to be an animator or graphic designer. The other character, Kusworo, was portrayed as an Indonesian citizen studying in Cambridge University, 
England. In terms of portrayal, The Source culture has been presented fairly. However, to balance the proportion, more Source Culture Contents should be included in the tests; therefore, the tendency that cultural bias to be found can be minimized.

\section{Why the Teachers Included the Reading Passages in the Tests}

As English teaching in Indonesia applies the notion of genre-based approach, reading passages are considered as one of the main aspects in teaching and testing. Thus, teachers are required to select reading passages from various sources to be included in a test they develop. According to the interview, the main reason why the teacher included particular reading passages was due to the relevancy to the type of texts required in the tests. As for the consideration of cultural contents, the teachers explained that they were not aware of the needs to consider cultural contents and did not have time to focus on that issue. The elaboration of the findings will be presented in the subsequent sessions.

The teachers confirmed that the tests were responsible in developing the test. The progresstest (ulangan harian) was developed by the teacher assigned to teach particular classes. This test is implemented only to students under the responsibility of the teacher. On the other hand, the mid-term test (ulangan tengah semester) and final test (ulangan akhir sekolah) were developed by two teachers assigned in the same grade. The mid-term test and final test are implemented to students in the same grade, although one of the teachers developing the test is not assigned to teach particular classes. The teachers explained that they develop the test based on the curriculum and syllabus. They affirmed that they are aware of the notions of validity and reliability in developing a test. However, when the cultural issues in language testing were asked in the interview, the teachers answered that they do not give much concern to cultural contents of reading passages included in the test. Then, the proportion and portrayal of the contents related to the source culture, the target culture, and the international culture were not considered. The consideration of choosing reading passages mainly is whether the passages are in line with the required types of texts.

The main reasons why the teachers did not consider cultural contents in the reading passages are their unawareness and the urge to deal with final examination. They did not know that the status of English as an international language should be considered when choosing reading passages for a test. The unawareness of the teachers to balance the cultural contents in the reading passages of the test can lead to cultural bias and washback of the test. If cultural issues are not treated carefully in a test, to some extent some students may not be able to answer the questions since the reading is not in line with the cultural values they are familiar with. Furthermore, as cultural contents in reading passages influence how readers view the world (Aliakbari, 2004; Sherman, 2010), the washback can be related to how students view the world based on other people's culture. The prominent proportion and portrayal of particular cultures in reading passages can make students gradually confirm that those cultures are applicable. 
Problems occur when the cultures prominently portrayed in reading passages are not in line with values and ideologies of the nation. The teachers developing the tests may not be aware of the possibility of washback since the tests might be accepted in the level of validity and reliability (Fulcher and Davidson, 2007).

It is also explained that they have to focus on preparing students for final examination. They claimed that cultural issues are not going to be tested in final examination. The teaching and the school testing then seem to be driven by the urge to pass the final examination. It confirms Hamied (2010) explaining that final examination as a high stake testing in Indonesia drives teacher to teach what is going to be tested in the final examination.

\section{CONCLUSION}

The research found that the reading passages of the tests contain the source culture, the target culture, the international culture, and culture-neutral items. The culture neutral reading passages comprise $41.67 \%$, while reading passages containing cultural items comprise $58.33 \%$ of the total reading passages in the tests. Among reading passages containing culture contents, the target culture and the international culture contents share the same proportion. The target culture comprises $40 \%$ of cultural contents in the forms of naming, place, and seasons and the international culture also comprises the cultural contents by $40 \%$ in the forms of naming, place, and seasons. The source culture comprises the least proportion with only $20 \%$ of cultural contents found in the forms of naming and place.
The teachers developing the tests explained that they did not concern about the proportion and portrayal of cultural contents in the reading passages of the tests. They did not realize that the tests designed by them resulted in the proportion and portrayal found in this research. In addition, preparation of National Examination is also considered as the reason why cultural contents were not concerned in test development process. Hence, it can be concluded that the proportion of cultural contents found in reading passages of the test was not intentionally designed. The unbalance proportion of cultural contents and unawareness of culture in developing a test can lead to cultural bias in a test and influence test takers' points of view toward particular culture.

Based on the findings, it is recommended that teachers be more aware of the influences of cultural content in reading passages of the test to the issue of cultural bias. Teachers should also be aware that cultural contents in reading passages of the test can influence points of view of students toward particular culture. Moreover, it is also recommended that teachers take into consideration the balance proportion and portrayal of cultural contents in reading passages selected for a test. That way, the cultural bias in a test can be minimized and the functions of English as an international language bridging intercultural understanding can be optimized.

\section{REFERENCES}

Adaskou, K., Britten, D., \& Fahsi, B. (1990). ELT Journal. Design decisions on the cultural content 
of a secondary English course for Morrocco, 44(1), 3-10.

Aliakbari, M. (2004). The Place of Culture in the Iranian ELT Textbooks in High School Level. The 9th Pan-Pacific Association of Applied Linguistics Conference. Seoul: Namseoul University [online: http://www.paaljapan.org/resour ces/proceedings/PAAL9/pdf/Ali akbari.pdf accessed on 02 Desember 2013].

Alsup, J. (2008). Teacher Identity

Discourses: Negotiating Personal and Professional spaces. New Jersey: Lawrence Erlbaum Associates Inc.

Anaxagorou, G. (2007). Teachers' and community stakeholders' perceptions on schoolcommunity relations in Cyprus. International Journal about Parents in Education, 1, 53-58.

Arnold, M. L., Newman, J. H., Gaddy, B. B., \& Dean, C. B. (2005). A look at the condition of rural education research: Setting a difference for future research. Journal of Research in Rural Education, 20(6), 1-25.

Ary, D., Jacobs, L. C., Sorensen, C., \& Razavieh, A. (2010). Introduction to Research in Education 8th Edition. Wadsworth: Cengage Learning.
B.Levin, B. (2003). Case Studies of Teacher Development: An InDepth Look at How Thinking About Pedagogy Develops Over Time. London: Lawrence Erlbaum Associates Publishers.

Bailey, C. S. (2007). A Guide to Qualitative Field Research 2nd Edition. Thousand Oaks: Pine Forge Press.

Ball, D. L., \& Cohen, D. K. (1999). Developing practice, developing practitioners: Toward a practicebased theory of professional education. In S. G., \& D.-H. L., Teaching as the learning profession: Handbook of policy and practice (pp. 3-32). San Fransisco: Jossey Bass.

Brown, G. T. (2004). Teachers' conceptions of assessment: implications for policy and professional development. Assessment in Education, 11(3), 301-318.

Brown, H. D. (2000). Teaching by Principles: An Interactive Approach to Language Pedagogy. New York: Longman.

Calderhead, J., \& Shorrock, S. B. (1997). Understanding Teacher Education. London: The Falmer Press. 
Canagarajah, S. (2007). Lingua Franca

English, Multilingual

Communities, and Language

Acquisition. The Modern

Language Journal, 91, 923-939.

Cortazzi, M., \& Jin, L. (1999). Cultural

Mirror: Materials and methods

in the EFL Classroom. In E.

Hinkel (Ed.), Culture in Second

Language Teaching and

Learning (pp. 196-219). New

York: Cambridge University

Press.

Cristopher, D. (1999). British Culture:

An Introduction. London:

Routledge.

Crystal, D. (2003). English as a Global

Language (second ed.). New

York: Cambridge University

Press.

Djiwandono, P. I. (2006). Cultural Bias in Language Testing. TEFLIN

Journal, 17(1), 81-89.

Dudley-Evans, T., \& John, M. J. (1998).

Develoments in English for Spesific Purposes. Cambridge:

Cambridge University Press.

Elgar, A. G. (2009). Culture Through Literature in Foreign Language Teaching. In J. Arabski, \& A. Wojtaszek (Eds.), Aspects of Culture in Second Language Acquisition and Foreign Language Learning (pp. 139150). Berlin: Springer.
Evans, L. (2002). What is Teacher Development? Oxford Review of Education, 28, 123-137.

Forshee, J. (2006). Culture and Customs of Indonesia. Connecticut: Greenwood Press.

Fraenkel, J. R., Wallen, N. E., \& Hyun, H. H. (2012). How to Design and Evaluate Research in Education (eight ed.). New York: McGraw Hill.

Fraenkel, J. R., Wallen, N. E., \& Hyun, H. H. (2012). How to Design and Evaluate Research in Education (eight ed.). New York: McGraw Hill.

Frey, L., Botan, C., \& Kreps, G. (1999). Investigating Communication: An Introduction to Research Methods. Boston: Allyn \& Bacon.

Fulcher, G., \& Davidson, F. (2007). Language Testing and Assessment: an Advanced Resource Book. New York: Routledge.

Gass, S. M., \& Selinker, L. (2008). Second Language Acquistion (third ed.). London: Routledge.

Gebhard, J. G. (2000). Teaching English as a Foreign or Second Language. USA: The University of Michigan Press. 
Goodwyn, A. (1997). Developing English Teachers: The role of mentorship in a reflective profession. Buckingham: Open University Press.

Guskey, T. (2002). Professional Development and Teacher Change. Teachers and Teaching: Theory and Practice, 8(3), 381-391.

Hamied, F. A. (2010). EFL Assessment in Indonesia: National Exams and Quality of Education. In Y.i. Moon, \& B. Spolsky, Language Assessment in Asia: Local, Regional or Global? (pp. 99-120). Seoul: Asia TEFL.

Hermawan, B., \& Noerkhasanah, L. (2012). Traces of Cultures in English Textbooks for Primary Education. Indonesian Journal of Applied Linguistics, 2(1), 4961.

Hinkel, E. (1999). Introduction: Culture in research and second lanugage pedagogy. In E. Hinkel (Ed.), Culture in Second Language Teaching and Learning (pp. 127). New York: Cambridge University Press.

Holmes, J. (2001). An Introduction to Sociolinguistics (second ed.). Edinburgh: Pearson Education Limited.
Hutchinson, T., \& Torres, E. (1994). The Textbook as Agent of Change. ELT Journal, 48(4), 315-328.

Jenkins, J. (2009). World Englishes: A Resource Book for Student (second ed.). London: Routledge.

Joys, B., \& Showers, B. (2002). Student Achievement through Staff Development. Alexandria: Association for Supervision and Curriculum Development.

Kachru, Y., \& Smith, L. E. (2008). Cultures, Contexts, and World Englishes. London: Routledge.

Kementrian-Pendidikan-danKebudayaan. (n.d.). Tujuan Pendidikan Nasional. Retrieved 12 31, 2013, from Kementrian Pendidikan dan Kebudayaan: kemdikbud.go.id/pages/purpose/ .html

Kramsch, C. (1991). Culture in Language Learning. In K. De Bot, R. B. Ginsberg, \& C. Kramsch (Eds.), Foreign Language Research in CrossCultural Perspective (pp. 217240). Amsterdam: John Benjamins.

Kramsch, C. (1998). Language and Culture. Oxford: Oxford University Press. 
Matsuda, A. (2003). Incorporating World Englishes in Teaching English as an International Language. TESOL Quarterly, 37(4), 719-729.

McGrath, I. (2002). Materials Evaluation and Design for Language Teaching. Edinburgh: Edinburgh University Press.

McKay, S. L. (2003). EIL Curriculum Development. RELC Journal, 34(1), 31-47 [online: http://rel.sagepub.com/content/3 4/1/31 accessed 27 November 2013].

Meade, A. W., \& Fetzer, M. (2009). Test Bias, Differential Prediction, and a Revised Approach for Determining the Suitability of a Predictor in a Selection Context. Organizationl Research Methods, 12(4), 738761.

Mukeredzi, T. G. (2013). Professional Development Through Teacher Roles: Conceptions of Professionally Unqualified Teachers in Rural South Africa and Zimbabwe. Journal of Research in Rural Education, 28(11), 1-17.

Oettli, P. (2009). New Zealand: Culture Shock - A Survival Guide to Customs and Etiquette. New York: Marshall Cavendish Corporation.
Olajide, S. B. (2010). A Critical Assessment of the Cultural Content of Two Primary English Textbooks Used in Nigeria. Journal of Language Teaching and Research, 1(5), 656-661.

Piller, I. (2001). Naturalization Language Testing and Its Basis in Ideologies of National Identity and Citizenship. International Journal of Bilingualism, 5(3), 259-277.

Sandra, H. H. (2003). Teacher Professional Development: It's Not an Event, It's a Process. Texas: CORD.

Shearer, B. F. (2008). Culture and Customs of The United States. London: Greenwood Press.

Sherman, J. E. (2010). Multiple Levels of Cultural Bias in TESOL Course Books. RELC Journal, 41(3), 267-281.

Thwaites, T., Davis, L., \& Mules, W. (1994). Tools for Cultural Studies: An Introduction. Melbourne: Macmillan Education Australia PTY LTD.

Vijver, F. v., \& Tanzer, N. K. (2004). Bias and Equivalence in CrossCultural Assessment: An Overview. Elsevier, 54, 119135. 
bahasa \& sastra, Vol.15, No.2, Oktober 2015

Villegas-Remers, E. (2003). Teacher Professional Development: An International View of the Literature. Retrieved from UNESCO website: http://unesdoc.unesco.org/image s/0013/001330/133010e.pdf.

Vivelo, F. R. (1997). Cultural Anthropology Handbook: A Basic Introduction. London: SAGE Publications Ltd.

Weir, C. J. (2005). Language Testing and Evaluation: An Evidence Based Approach. New York: Palgrave Macmillian.
Xiao, J. (2010). Cultural Contents of an in-use EFL Textbooks and English Major Students' Attitude and Perceptions towards Culture Learning at Jiangxi University of Science and Technology, China. Thesis Unpublished Material Submitted to The Graduate School Prince of Songkla University.

Yano, Y. (2001). World Englishes in 2000 and Beyond. World Englishes, 20(2), 119-131. 